\title{
Association between Investment, Production, Export and Import: The Impact of Labor Force Absorption in Indonesia
}

\author{
Andi Sessu \\ (Faculty of economics and business UHAMKA Jakarta)
}

\begin{abstract}
This study produced several important findings, namely: (a) trade, especially foreign trade (exports and imports) and domestic production which increases the expansion of employment opportunities; $(b)$ economic growth as measured by the growth of production and growth in investment showed an influence on the improvement of employment opportunities; and (c) Simultaneously, export, import, production and investment have a significant effect on employment. In connection with this, the Central Government of the Republic of Indonesia must continue to promote investment, especially sector Agroindustry and other agriculture-based industries, including fertilizer and pesticide industries. Imports of used clothing and used tires must be stopped to allow the national industry sector to recover profitable economic capacity. The agricultural sector must still get attention, especially food crops such as soybean, corn and rice and fruit to strengthen national food agriculture and agriculture-based industries as well as save on foreign exchange
\end{abstract}

KEYWORDS : Export, Import, Production, Investment and Labor Absorption

\section{INTRODUCTION}

The integration of the world economy and trade policy is essential for development, job creation and poverty alleviation (Trade and Development Commission, UNCTAD, 2013). Foreign Direct Investment (FDI) has been shown to have encouraged local and regional economic growth, especially in developing countries in Asia, Africa and Latin America. It is to create jobs and alleviate poverty (Tambunan, 2005). The success of the economic development of a country is characterized by two main things, namely economic growth and poverty reduction. To alleviate this poverty, require job growth and an increase in income per capita (Jonaidi, 2012; Susilo, 2013).

Associated with the condition of Indonesia, a major problem faced is the phenomenon of labor surplus economy, a country which population growth is greater than the growth of their employment. Therefore, appropriate economic policies implemented in Indonesia are to encourage economic sectors which can immediately increase employment opportunities. The growth of industrial sector should be encouraged, especially subsector Agroindustry (agriculture based industries). The development of agriculture-based industries will contribute double benefits. In addition increasing the added value of agricultural products, agricultural employment and industrial sector will also increase. Along with it, the income of farmers is encouraged to increase in the future thus simultaneously reducing poverty.

According to Fei-Ranis models, shifting agricultural labor to the industrial sector took place in three stages based on the marginal physical product (MPP) and wages which assumed to be constant and exogenously determined. In the first stage, despite the transfer of power from agricultural sector to industrial sector, agricultural production will not fall because, agricultural laborers are redundant. In the second stage, the production of the agricultural sector began to decline because labor MPP had positive start. In the third stage is the stage of commercialization of the two sectors of the economy. MPP labor becomes higher than the level of wages. Agricultural producers will maintain its workforce thus each sector seeks to be streamlined. Transfer will continue to happen if the technological innovation in the agricultural sector can boost labor MPP (Kariyasa, 2006).Based on the ideas that have been put forward, then the following is the distribution of employment by economic sector: 


\section{Table 1. Employment by Industry and Status}

\begin{tabular}{|lccccc}
\multicolumn{1}{c}{ Employment by Industry } & $\mathbf{2 0 0 2}$ & $\mathbf{2 0 0 5}$ & $\mathbf{2 0 0 8}$ & $\mathbf{2 0 1 1}$ & $\mathbf{2 0 1 2}$ \\
agriculture (\%) & 44.30 & 44.00 & 40.30 & 35.90 & 35.20 \\
Manufacturing Industry (\%) & 13.20 & 12.70 & 12.20 & 13.30 & 13.90 \\
Trading (\%) & 19.40 & 19.10 & 20.70 & 21.30 & 20.90 \\
Services (\%) & 17.50 & 18.20 & 20.20 & 22.20 & 22.40 \\
Others (\%) & 5.50 & 6.00 & 6.50 & 7.30 & 7.60 \\
$\quad$ T T o t a l & 100.00 & 100.00 & 100.00 & 100.00 & 100.00 \\
\multicolumn{1}{c}{ Employment by Status } & & & & & \\
Freelance (\%) & 19.20 & 18.40 & 20.40 & 17.70 & 16.60 \\
Assisted by Not Fixed Labor (\%) & 24.00 & 22.30 & 21.20 & 17.90 & 16.90 \\
Assisted by Fixed Labor (\%) & 3.00 & 3.00 & 2.90 & 3.40 & 3.50 \\
Labor / Employee / Servant (\%) & 27.30 & 27.70 & 27.50 & 34.40 & 36.40 \\
Freelancer in Agriculture (\%) & 4.90 & 5.90 & 5.80 & 5.00 & 4.80 \\
Freelancer in Non-Agricultural (\%) & 3.90 & 4.60 & 5.20 & 5.10 & 5.60 \\
Work with Family / Unpaid (\%) & 17.60 & 18.00 & 16.90 & 16.40 & 16.20 \\
$\quad$ T o t a l & 100.00 & 100.00 & 100.00 & 100.00 & 100.00
\end{tabular}

Source: Indonesia Minimum Wage Policy (wcms_210427/BPS, 2013)

Table 1 has explained that there has been a transfer of labor from agriculture to other economic sectors. Employment in agricultural sector has decreased 5.6 percent per year, while other economic sectors had increased. The industrial sector increased by 1.3 percent, the trade sector rose 1.9 per cent, the service sector rose 6.4 percent and other economic sectors increased by 8.4 percent per year. In connection with that, this study aims to analyze the relationship between investment, production, exports, and imports as well as the Impact on Labor Absorption in Indonesia. This analysis is expected to answer the question, how much impact the growth of production and investment towards employment absorption capacity of the existing workforce.

There are three jobs that are the most widely demanded, there are laborers / employees / workers (average 30.66\%). Helped by temporary workers are in average of 20:46 percent. Entrepreneur is in average of 18:46 percent. Indicating that being entrepreneur has not occupied a dominant position. This may be an indication that the entrepreneurs in Indonesia have been inadequate in number. To encourage adequate employment, the educational entrepreneurs must be fostered.

\section{REVIEW OF LITERATURE}

\subsection{Investment}

Investment is capital expenditure at the present time to obtain greater benefits in the future. Investments can be made using domestic investment and foreign investment. Investment through domestic resources derived from public savings and government savings. Sources in this country may be greatest if the community has the ability to set aside more of their income for consumption purposes. The level of income per capita that is low becomes a major obstacle in mobilizing public savings to finance investment. This caused the government must provide an opportunity for foreigners to invest. Investment is an important component in stimulating economic growth and creating jobs in a more sustainable manner. Investments can be created through the investment of domestic and foreign investment or foreign direct investment (FDI). Investments should be made on the leading sector, such as the manufacturing sector and Agroindustry. Foreign Direct Investment (FDI) plays an important role in enhancing the capacity of key sectors of the national economic, such as crude oil or some branch of the manufacturing industry sectors such as textiles and garments, footwear industry and service sectors such as telecommunications, transport and financial services (Cu Chi Loi , 2010).

Investing requires a conducive business environment and appropriate government policies. Currently, the effort to improve the business climate has been done but not optimal. Investments include all domestic spending by governments and the private sector aims to establish new factories, increasing capacity and quality of service industries, building economic infrastructure. Investment is the demand for goods and services to create or increase production capacity and revenue in the future (Dornbusch, Fischer \& Startz, 2004). 
Economic growth model which was developed from Keynes's theory focuses on the role of savings and investment. When an economy has the capacity savings, then these savings can be used for the capital for the achievement of economic growth of a country. There is a positive correlation between investment and economic growth (Arsyad, 2005; Harrod-Domar in Mukhlis, 2012). Another study found a high correlation between savings with investment (Feldstein \& Horioka, 1980). The success of economic growth cannot be separated from the increasing investment. Investment is the rate of growth determinants. Besides, the output, the investment also will automatically increase the demand for inputs, which in turn will increase employment and social welfare. (Ma'mun \& Yasin, 2003).

\subsection{Production}

Production capacity of an economy shows the limits of the economy to produce goods and services. Where all are used in full capacity. The number of jobs provided by the sector service industries related to all export activities that consider the relationship directly or indirectly carrying are larger than the total number of jobs created by all manufacturing exports (Relavan in Hengki Issakh Idris, 2013). Economic growth occurs when there is a rise in the real gross national product or national income rill. The economy is said to grow in case of real output growth. Economic growth which illustrates the increase in the standard of living measured by real output per person. Economic growth as a continuous rise in product per capita or per worker. It is often accompanied by the increase in population and usually also by structural changes (Todaro, 2003; Kuznets in Jhingan, 2004).

Economic growth showed the extent to which economic activity would generate additional income. Because basically economic activity is a process of using the factors of production to produce output (Mankiw, 2003). Some existing models, including models of neo-classical theory developed by Solow is a major growth in the 1960s designed to show how the growth in savings and capital stock, population growth, and advances in technology interact in economic growth. It also explains how they affect the total output of goods and services a country. This model states that the output depends on the capital stock and labor force. Assuming that the production process has a constant scale returns. Economic growth depends on the increase supply of factors of production; population, labor, and capital accumulation (Badrudin, 2012).

The model of growth as indicated by the equation $\mathrm{Y}=\mathrm{F}(\mathrm{K}, \mathrm{L})$ that national output is a function of the inputs used in the production process, which in this case is assumed to consist of capital factor $(\mathrm{K})$ and labor factor (L). This function is an aggregate for connecting between the total economic output of the total amount of the two main factors that are used to produce the output (Solow, 1956). There are three factors or major component of economic growth. First, the accumulation of capital which includes all forms and types of new investments were invested in land, physical equipment and human resources. Second, population growth in the next few years by itself bring labor force growth. Third, advances in technology (Todaro, 2003). The indicators used to measure economic growth is the growth rate of Gross Domestic Product (GDP) (Mankiw, 2003).There are several underlying reasons for the selection of economic growth using Gross Domestic Product (GDP), which is that GDP is the total value added generated by all productive activity in the economy, this means an increase in the GDP also reflects an increase in remuneration to the factors of production used in the production activity.

\subsection{Export and Import}

The main factor that causes the direction of the flow of exports and imports is the improvement in the trade balance. Surplus trade balance on goods will be able to adequately cover the services trade deficit and the deficit in capital flows. Effect of increase in exports against imports are equal to the effect of increased investment against imports, but in terms of the balance of payments, the effect of changes in exports is not as big as the effect of changes in investment. Increased imports as a result of increased investment are usually not preceded by an increase in exports. Increase in exports is always tendentious to decreasing the balance of deficit payment, otherwise the decline in the value of exports has always resulted in increased deficits or declining balance of payments surplus. Improved trade balance requires rapid export growth. 


\subsection{The Employment}

Population growth will clearly add to the number of items used, but the proportion will greatly depend on the increase in employment. If the population growth was accompanied by the increase in employment, it will be more receiving income. So that consumer purchasing power will increase. Labor is the one who do the work in order to produce goods or services to meet the needs of themselves and society (the Law of the Republic of Indonesia No. 13 of 2003).

Employment is one factor supporting economic development undertaken by developing countries aimed at creating equitable economic development. Based on the Law of the Republic of Indonesia Number 13 of 2003, Article 1, paragraph 2 defines employment as follows: "Labor is any person who is able to work in order to produce goods and / or services to meet the needs of themselves and for society" One attempt to improve employment is through the development in the industrial sector. Development in the industrial sector is part of a long-term effort to improve the unbalanced economic structure.

\subsection{Labor Absorption}

The level of relatively high population growth affects the growth of the labor force. The greater the number of working-age population, hence labor force will grow, both as workers and as a job seeker. The labor force is the workers who work and looking for work. Labor are all working age population (15-59 years of age according to the concept of ESCAP, 15-64 years according to the International concept and 10 years and over according to the concept of Indonesia (BPS, 2000). Finding a job is also called unemployed i.e. those who conduct job search. Job opportunities and unemployment can be calculated by using the following formula:

$$
\text { Employment opportunity }=\frac{\text { Number of job }}{\text { Number of labor }} \times \mathrm{k}
$$

$$
\text { Unemployment }=\frac{\text { Number of unemployed }}{\text { Number of labor }} \times \mathrm{k}^{1}
$$

Where: $\mathrm{k}=$ constant number (worth 100)

Labor Force Absorption Rate (LFPR) is the ratio of the number of labor force to the working age population (15 years and above). In this case the meaning of the labor force is the number of people working and looking for work. While the working age population is composed of the labor force and not the labor force, LFPR shows the magnitude of the working age population that is working and looking for work. The absorption rate of the labor force can be written:

$$
\mathrm{TPAK}=\frac{\sum \mathrm{AK}}{\sum \mathrm{UK}} \times 100 \%
$$

Where:

Ak = Labor force,

UK = Working age population.

The labor force consists of employed and unemployed population. While that is not the workforce is comprised of people who in the reference period does not perform economic activities, either because of school, taking care of the household or the other. While the definition of working is doing activities with the intent to obtain or help earn income for at least one hour a week. Worked for an hour should be done consecutively and uninterrupted. Unemployment includes people without working, looking for work, preparing for a new business or have been accepted to work but have not started working. Looking for work defines as the effort which is made to obtain a job at one period of reference. 


\section{METHODS}

This research was conducted by using survey method. The data used is secondary data collected through research documents in the National Central Bureau of Statistics in Jakarta. Data were analyzed using correlation and multiple regression analysis (Ghozali, 2005). The value of each variable analysis of the algorithm values previously withdrawn, except with respect to the analysis of growth.

The design of the research model is as follows:

$$
\begin{aligned}
& \log Y=b_{0}+b_{1} \log X_{1}+b_{2} \log X_{2}+b_{3} \log X_{3}+b_{4} \log X_{4}+e_{i} \ldots \ldots \ldots \text { (a) } \\
& \Delta Y=b_{0}+b_{3} \Delta X_{3}+b_{4} \Delta X_{4}+e_{i} \ldots \ldots \ldots \ldots \ldots \ldots \ldots \ldots \ldots \ldots \ldots \ldots \ldots \ldots \ldots \ldots \ldots \ldots \ldots \ldots \ldots \ldots \ldots \ldots \ldots \ldots \ldots \ldots \ldots \ldots \ldots \ldots \ldots \ldots
\end{aligned}
$$

Where :

$\log \mathrm{Y}=$ absorbed labor

$\log X_{1}=$ exports value

$\log X_{2}=$ imports value

$\log \mathrm{X}_{3}=$ production value

$\log \mathrm{X}_{4}=$ investment value

$\Delta \mathrm{Y} \quad=$ changes in absorption of labor

$\Delta \mathrm{X}_{3}=$ production growth

$\Delta \mathrm{X}_{4}=$ investment growth

$\Delta \mathrm{Y} \quad=\frac{Y_{t}-Y_{t-1}}{Y_{t-1}} \times 100$, and the same process is carried out in calculating $\Delta \mathrm{X}_{3}$ and $\Delta \mathrm{X}_{4} \cdot Y_{t}=$ labor absorption in year into $\mathrm{t}$, and $Y_{t-1}=$ labor absorption in the previous year.

In addition, the data were also analyzed by using multiple correlation analysis with the intention to measure the relationship of independent variables studied with labor is absorbed. Regression analysis was performed as a measure of the effect of each independent variable analyzed toward labor absorbed.

\section{RESULT}

Results of multiple correlation analysis of the model (a) generating correlation values in Table 2.

Table 2.

Multiple Correlation Analysis $\log Y=f\left(\log X_{1}, \log X_{2}, \log X_{3}, \log X_{4}\right)$

\begin{tabular}{|c|c|c|c|c|c|c|c|}
\hline No & Variables & $\log \mathrm{Y}$ & $\log \mathrm{X}_{1}$ & $\log \mathrm{X}_{2}$ & $\log \mathrm{X}_{3}$ & $\log \mathrm{X}_{4}$ & $\mathrm{p}$-value \\
\hline 1 & $\log \mathrm{Y}$ & 1 & & & & & - \\
\hline 2 & $\log \mathrm{X}_{1}$ & 0.959 & 1 & & & & 0.000 \\
\hline 3 & $\log \mathrm{X}_{2}$ & 0.928 & 0.980 & 1 & & & 0.000 \\
\hline 4 & $\log \mathrm{X}_{3}$ & -0.780 & -0.854 & -0.847 & 1 & & 0.001 \\
\hline 5 & $\log \mathrm{X}_{4}$ & -0.325 & 0.441 & -0.169 & 0.917 & 1 & 0.236 \\
\hline
\end{tabular}

Source: Data analyzed by SPSS of Appendix 1

Based on the correlation values in Table 2, it can be seen that the export, import and production are correlated significantly with workers absorbed. There are only investment is not significantly correlated. In addition, the interesting thing is the negative relationship between production $\left(\mathrm{X}_{3}\right)$ and investment $\left(\mathrm{X}_{4}\right)$ with workers absorbed $(\mathrm{Y})$. This means that the increase in exports and imports encourage increased labor force. As with the production and investment, has the opposite behavior. This occurs because the industrial sector in Indonesia is still using imported raw materials and the investment has not focused on agriculture-based industry (domestic resources). To explore the behavior of variable causality analysis, the following are presented results of the regression analysis, simultaneously and partially. 
Table 3. Analysis of Simultaneous Variables

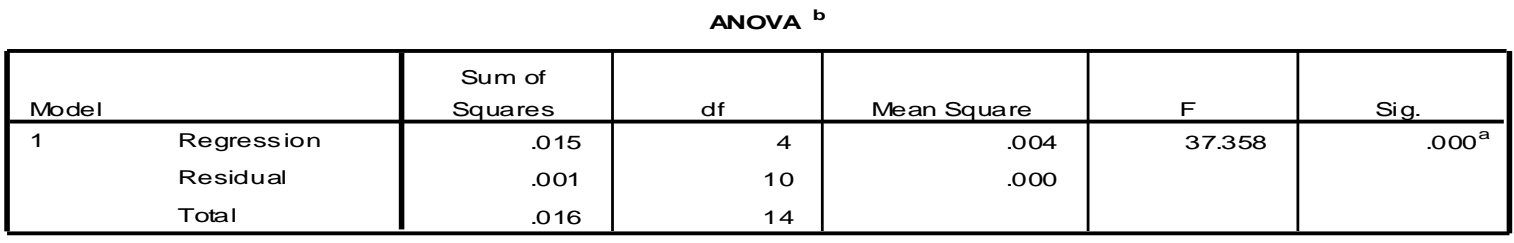

a. Predictors: (Constant), $\log X 4, \log \times 3, \log X 2, \log X 1$

b. Dependent Variable: LogY

Source: Data analyzed by SPSS of Appendix 1

Data Table 3 shows that simultaneously analyzed four independent variables that significantly influence the absorption of labor in various jobs. But partially, the conditions are presented in Table 4.

Table 4. Results of Analysis of Partial Independent Variable

\begin{tabular}{|c|c|c|c|c|c|c|}
\hline \multirow{2}{*}{\multicolumn{2}{|c|}{ Model }} & \multicolumn{2}{|c|}{$\begin{array}{c}\text { Unstandardi zed } \\
\text { Coefficients }\end{array}$} & \multirow{2}{*}{$\begin{array}{c}\begin{array}{c}\text { Standardi zed } \\
\text { Coefficients }\end{array} \\
\text { Beta }\end{array}$} & \multirow[b]{2}{*}{$t$} & \multirow[b]{2}{*}{ Sig. } \\
\hline & & $\mathrm{B}$ & Std. Error & & & \\
\hline \multirow[t]{3}{*}{1} & (Constant) & 5.506 & .659 & & 8.358 & .000 \\
\hline & $\log \times 1$ & .202 & .074 & 1.185 & 2.729 & .021 \\
\hline & $\log \times 2$ & -.023 & .050 & -.188 & -.456 & .658 \\
\hline
\end{tabular}

a. Dependent Variable: LogY

Source: Data analyzed by SPSS of Appendix 1

Analysis according to Table 4 generates the regression equation:

$$
\log Y=5.506+0.202 \log X_{1}-0.023 \log X_{2}+0.002 \log X_{3}-0.017 \log X_{4} .
$$

Table 4 shows that only exports are already having positive and significant impact. Although not significant in the production, but positive influence is on the export of labor absorption instead. As with the import and investment showed a negative relationship and influence, meaning that an increase in imports would result in a weakening of the economic absorptive capacity of the labor sector. Investment also showed the same behavior. Thus, some improvements in the field of investment policy are necessarily needed. Investment should be encouraged spaciousness effort to stimulate and encourage the development of export-based growth of the domestic industry and strengthen agriculture. ,Viewed from the angle of the impact of growth in domestic production and investment, hence the results of analysis are presented in Table 5.

Table 5. Impact of Production Growth and Investment

\begin{tabular}{|c|c|c|c|c|c|c|}
\hline \multirow{2}{*}{\multicolumn{2}{|c|}{ Model }} & \multicolumn{2}{|c|}{$\begin{array}{c}\text { Unstandardized } \\
\text { Coefficients }\end{array}$} & \multirow{2}{*}{$\begin{array}{c}\text { Standardi zed } \\
\text { Coefficients } \\
\text { Beta } \\
\end{array}$} & \multirow[b]{2}{*}{ t } & \multirow[b]{2}{*}{ Sig. } \\
\hline & & $\mathrm{B}$ & Std. Error & & & \\
\hline \multirow[t]{3}{*}{1} & (Cons tant) & 1.796 & .288 & & 6.227 & .000 \\
\hline & pertumbuhan & .008 & .007 & .275 & 1.058 & .313 \\
\hline & investasi & .008 & .005 & .426 & 1.638 & .130 \\
\hline
\end{tabular}

a. Dependent Variable: serapan

Source: Data analyzed by SPSS of Appendix 1 .

Based on data from Table 5, obtained a regression equation:

$\Delta Y=1.796+0.008 \Delta X_{3}+0.008 \Delta X_{4}$ 
Growth of Production and Investment Enhancement does not significantly influence the increase in labor absorption. However, the correlation and the effect were positive. Meaning that, there is the relationship and influence between production growth and development investment to increase labor absorption. These results indicate the need for central government support Indonesia in the field of real sector and investment. Business field should be developed is the field that is able to accelerate the rapid growth of employment. Business field should be encouraged is agriculture-based industries (Agroindustry).

Posture study variables can be seen in Figure 1.

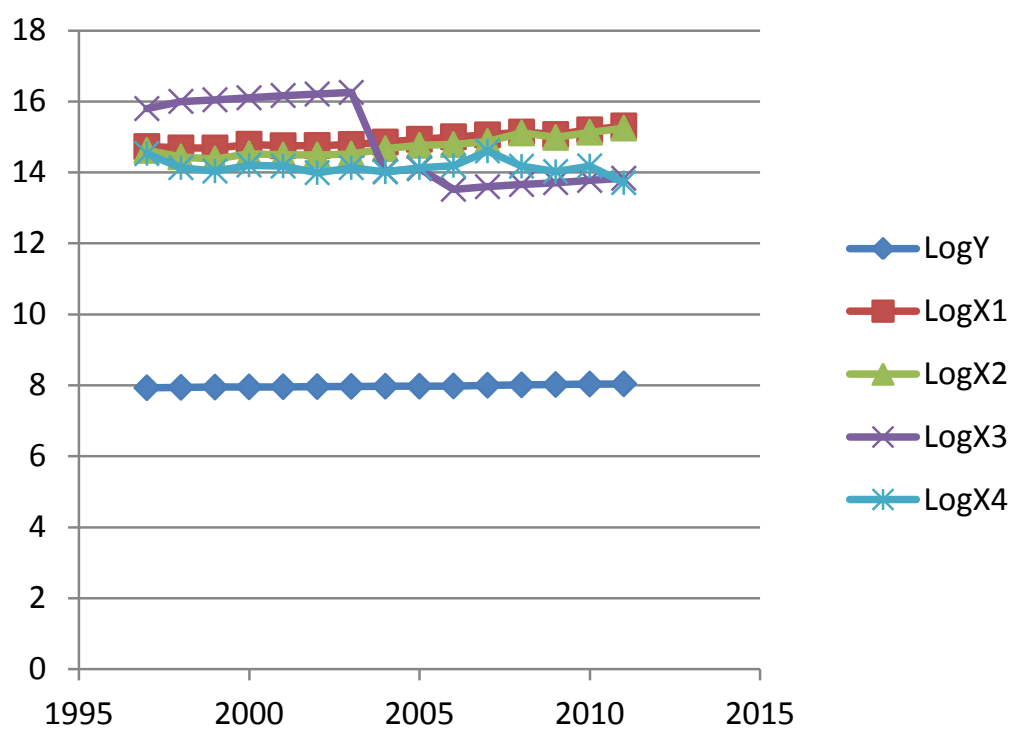

Figure 1. Variable Research Visual

Figure 1 illustrates that the actual export and import measured in rupiah in the period 1997-2011 is likely to increase. The value of production in the same period, precisely from 2004 to 2011 continued to decline. The symptoms are also seen in investment, though the decline of investment was not as big as production.

\section{DISCUSSION}

The analysis showed the relevance of the findings showed that investment in the form of FDI and economic growth affect the expansion of employment opportunities (Tambunan, 2005; Jonaidi, 2012; Susilo, 2013). The trade impact on a country's strong economy and its effect on employment (UNCTAD, 2013). The study also found that the trade, especially foreign trade (exports and imports) correlates strongly and positively with employment. The shift of labor to the agricultural sector and other economic sectors tend not to reduce agricultural production. Even it will increase the economic productivity (Kariyasa, 2006).

During the study period, it has been proven that the agricultural sector workforce has shifted to other economic sectors, such as manufacturing sectors, trade and services. But such a shift is followed by specific agricultural production, especially soybean and fruits. However, labor mobility agriculture and other economic to sector will still take place due to the attractiveness of wages in other sectors of the economy. Thus, the employment in manufacturing sectors needs to be increased. Only a shift in power agricultural sector must be followed with the right policy. Modernization of the agricultural sector needs to be done. Modernization of the agricultural sector needs to be done by giving priority to the development of agroindustry and agribusiness (Kurniati \& Yanfitri, 2010). Harrod-Domar theory sees the need to mobilize the community to increase the potential savings. Increased savings need to be followed by an increase in investment, particularly investment in the sector Agroindustry. All of these will encourage the expansion of employment opportunities (Rahayu, 2014). Businesses prosper society must start from the provision of employment opportunities for all residents.Through employment, people will earn sufficient income to meet the educational needs of children, health care and simultaneously increase income per capita. The constructive effort would be useful for eradicating the poverty (Khan, 2007). The findings of this study support the results of previous study that the Agroindustry sector needs to be developed as well as enhancing the investment. It will promote the development of labor absorption sectors of industry and agriculture. 


\section{CONCLUSION AND RECOMMENDATIONS}

Based on the results of the analysis can be concluded that trade (exports and imports) along with production is useful to increase employment opportunities. Economic growth is measured by the growth in production and investment growth shows its effect on increasing employment opportunities. Simultaneously, exports, imports, production and investment have a significant effect on employment.

Indonesian government is urged to keep encouraging investment, especially sector Agroindustry and other agriculture-based industries, including fertilizer and pesticide industries. Imports of used clothing and used tires must be stopped to allow the recovery of the industrial sector to do business profitably economic capacity. The agricultural sector must still get attention, especially food crops such as soybean, corn and rice, and fruits. It is intended to strengthen the national food agriculture and conserve foreign exchange.

\section{REFERENCES}

[1] Arsyad, Lincolin. (2005). Pengantar Perencanaan Pembangunan Ekonomi Daerah, Edisi Kedua, Penerbit BPFE: Yogyakarta

[2] Badrudin, Rudy. (2012). Ekonomika Otonomi Daerah. UPP YKPN, Yogyakarta

[3] Badan Pusat Statistik. (2000). Statistik Indonesia. BPS, Jakarta.

[4] ------------. (2013). Statistik Indonesia. BPS, Jakarta.

[5] $\mathrm{Cu}$ Chi Loi. (2010). Impact of Economic Integration on Employment and Poverty Reduction in Vietnam. Diakses tgl. 24 Maret 2015

[6] Dornbusch, Rudiger., Stanley Fischer, dan Richard Startz. (2004). Macroeconomics.. McGraw-Hill, Irwin

[7] Feldstein, Martin; dan Charles Horioka,. (1980). Domestic Saving and International Capital Flows, Economic Journal90 (358): 314-329, JSTOR 2231790

[8] Ghozali, Imam. (2005). Aplikasi Analisis Multivariate dengan Program SPSS. Badan Penerbit Universitas Diponegoro. Semarang

[9] Hengki Idris Issakh. (2013). Peluang Dan Tantangan ukm Dan Industri Jasa Indonesia Menghadapi Masyarakat Ekonomi ASEAN 2015. Candi Mas Metropole. Jakarta.

[10] Jhingan, M.L. (2004). Money, Banking, International Trade and Public Finance. Vrinda Publications, New Delhi, India.

[11] Jonaidi, Arius. (2012). Analisis Pertumbuhan Ekonomi dan Kemiskinan di Indonesia. Jurnal Kajian EkonomiVolume 1, Nomor 1, April 2012, pp. 140-164, diakses tgl. 24 Maret 2015

[12] Kariyasa, Ketut. (2006). Perubahan Struktur Ekonomi dan Kesempatan Kerja serta Kualitas Sumberdaya Manusia di Indonesia. Diunduh dari http://download.portalgaruda.org/article.php?article=13009\&val =926 tgl. 24 Maret 2015

[13] Khan, Azizur Rahman. (2007). Growth, Employment and Poverty: An Analysis of the Vital Nexus Based on Some Recent UNDP and ILO/SIDA Studies. DESA Working Paper No. 49 ST/ESA/2007/DWP/49. Diunduh tgl. 24 Maret 2015

[14] Kurniati, Yanti dan Yanfitri. (2010). Dinamika Industri Manufaktur dan Respon Terhadap Siklus Bisnis. Buletin Ekonomi Moneter dan Perbankan, Oktober 2010, pp. 135-168, Jakarta

[15] Mankiw, N. Gregory. (2003). Teori Makroekonomi. Edisi Kelima. Erlangga. Jakarta

[16] Mukhlis, Imam. (2012). Aliran Foreign Domestic Investment dan Produk Dometik Bruto Indonesia. Jurnal IESP, FE Universitas Negeri Malang, Vol. 4 No.2 November 2012, pp. 191-200

[17] Makmun dan Ahmad Yasin. (2003). Pengaruh Investasi dan Tenaga kerja Terhadap PDB Sektor Pertanian, Jurnal Kajian Ekonomi dan Keuangan Vol.7 No.3 September

[18] Rahayu, Teguh Imam. (2014). Teori Pembangunan Dunia ke-3 Dalam Teori Modernisasi Sub Teori Harrod-Domar (Tabungan dan Investasi). Diunduh dari http://download.portalgaruda.org/article.php?article=142386 \&val=5460 tgl. 24 Maret 2015

[19] Republik Indonesia. (2003).Undang-Undang Republik Indonesia No. 13 Tahun 2003 tentang Ketenagakerjaan.

[20] Solow, Robert M. (1956). A Contribution to the Theory of Economic Growth. The Quarterly Journal of Economics, Vol. 70, No. 1. pp. 65-94.

[21] Susilo, Heru Prasetyo. (2013). Pengaruh Investasi dan Tenaga Kerja terhadap Output Sektor Industri Kecil: Analisis Panel Data. Jurnal Studi Ekonomi Indonesia Fakultas Ekonomi Universitas Sebelas Maret, diakses dari situs: http://eprints.uns.ac.id/1796/1/1-1-1-PB.pdf, tgl. 24 Maret 2015

[22] Tambunan, Tulus. (2001). Perekonomian Indonesia: Teori dan Temuan Empiris. Jakarta, Ghalia Indonesia.

[23] Todaro, Michael P. (2003). Economic Development. Edisi 8 (terjemahan). Penerbit Erlangga, Jakarta

[24] Trade and Development Board UNCTAD. (2013). The Impact of Trade on Employ-ment and Poverty Reduction. UN Conrference on Trade and Development, Jenewa 2013, Diakses tgl. 24 Maret 2015 
Appendix 1.

Export, Imports, Production, Investment and Labor Absorption

\begin{tabular}{|c|c|c|c|c|c|}
\hline Year & $\begin{array}{c}\text { Export } \\
(\mathbf{R p})\end{array}$ & $\begin{array}{c}\text { Imports } \\
(\mathbf{R p})\end{array}$ & $\begin{array}{c}\text { Production } \\
(\mathbf{R p})\end{array}$ & $\begin{array}{c}\text { Investment } \\
(\mathbf{R p})\end{array}$ & $\begin{array}{c}\text { Labor } \\
(\text { People })\end{array}$ \\
\hline 1997 & 534436000000000 & 416798000000000 & 6276955190000000 & 338444872900000 & 85050000 \\
\hline 1998 & 488476000000000 & 273369000000000 & 10023330000000000 & 135691749300000 & 87290000 \\
\hline 1999 & 486655000000000 & 240033000000000 & 11099795000000000 & 108959550000000 & 88820000 \\
\hline 2000 & 621240000000000 & 335148000000000 & 12649187480000000 & 160851327700000 & 89840000 \\
\hline 2001 & 563209000000000 & 309621000000000 & 14676548350000000 & 150617672900000 & 90810000 \\
\hline 2002 & 571588000000000 & 312889000000000 & 16105649510000000 & 97916307600000 & 91650000 \\
\hline 2003 & 610582000000000 & 330859000000000 & 17866909190000000 & 136012092100000 & 92810000 \\
\hline 2004 & 715846000000000 & 465245000000000 & 106100810000000 & 102835140400000 & 93720000 \\
\hline 2005 & 856600000000000 & 577009000000000 & 127048390000000 & 135490576400000 & 93960000 \\
\hline 2006 & 1007986000000000 & 610655000000000 & 33392168000000 & 156342767200000 & 95460000 \\
\hline 2007 & 1141009000000000 & 744734000000000 & 39508932000000 & 401646870300000 & 99930000 \\
\hline 2008 & 1370204000000000 & 1291974000000000 & 45513587000000 & 148734303400000 & 102550000 \\
\hline 2009 & 1165100000000000 & 968292000000000 & 51414144000000 & 105190799900000 & 104870000 \\
\hline 2010 & 1577791000000000 & 1356633000000000 & 59362378000000 & 152195525300000 & 108210000 \\
\hline 2011 & 2034966000000000 & 1774356000000000 & 67943734000000 & 51323022400000 & 109670000 \\
\hline
\end{tabular}

Source: Results of research 